\title{
FDI and Multinationals: Patterns, Impacts and Policies
}

\author{
GUEST EDITORS: ANA TERESA TAVARES and STEPHEN YOUNG*
}

This Special Issue brings together eight articles dealing with a group of very topical aspects concerning recent patterns in FDI and multinationals' (MNEs) activities, MNEs' impacts in different host economies (especially regarding linkages with domestic firms, and productivity spillovers), the dynamic interaction between inward-outward investment, and, above all, policy vis-à-vis MNEs. A strong policy focus is the common thread linking the papers presented here, as all debate thoroughly the policy implications of the results obtained, and question some common recipes used to attract and embed international investors.

The articles show that, given the complexity of the issues tackled and the heterogeneity of the impact scenarios, there are no quick fixes or easy responses. However, this does not preclude a serious discussion of the topics and, based on solid empirical evidence, the suggestion of specific policy options.

The articles in this Special Issue mostly focus upon inward FDI and foreignowned MNEs. However, some of the most interesting conclusions concern domestic firms, and particularly those that have undertaken outward FDI and become multinationals in their own right. Inward and outward FDI are linked, of course, as is discussed shortly, although the fact that policy-makers have generally yet to make the specific connection (hence fully understanding what this interaction means for competitiveness and development) has important implications.

\section{Inward FDI and Public Policy}

The articles focusing on inward investment contribute to the ongoing debate about MNEs' impacts on their host economies, often questioning conventional wisdom and overall providing new robust empirical evidence on the effects of multinationals' activities. The two main policy-related themes emerging concern, first, the promotion of FDI from abroad, and the role of incentives to inward investors; and second, policies to enhance the economic contribution of inward FDI through spillovers. The authors' contributions indicate that there is no new magic wand and that policy-based success is elusive. The Irish case, as presented

\footnotetext{
*The Guest Editors would like to thank the Editors of this journal for their encouragement and support. Sincere thanks are also due to their respective universities; and to everyone who assisted with and participated in the EUNIP Conference at the University of Porto (2003).

Ana Teresa Tavares, Centro de Estudos Macroeconómicos e Previsão, Faculty of Economics, University of Porto, Portugal; e-mail: attavares@fep.up.pt; Stephen Young, Strathclyde International Business Unit, Strathclyde Business School, Glasgow G4 0RQ, UK; e-mail: stephen.young@strath.ac.uk
} 
in the papers of Barry et al. and Ruane and Ugur in this volume, is an exception; but even here the effectiveness of policies to enhance spillovers is questioned.

\subsection{Attracting Inward Investment: an Increasingly Proactive and Tough Race}

Nowadays nearly all countries promote inward investment (UNCTAD, 2003). Even former sceptics in Latin America, the Middle East and Japan scramble to win FDI projects, engaging in tough locational tournaments (Mytelka, 2000) or in what qualifies as a genuine 'race' (Ghauri and Oxelheim, 2003). Even in Europe, several economies have abandoned their traditional cautious approach, engaging in proactive FDI policies (in this Issue, Piscitello and Rabbiosi, and De Propris et al. highlight this approach in Italy; the same happened in other EU countries, e.g., Portugal and Spain), implementing investor-friendly measures, and initiating specific institutional developments like the opening of investment-promotion agencies (Tavares and Young, 2003). The same has occurred in most Central and Eastern European Countries (CEECs).

\subsection{The Role of FDI Incentives}

Incentive concession has become a common practice in most countries, usually legitimated by the 'stylized fact' that inward investors have normally superior performance compared with domestic firms. This is a highly relevant area of policy debate, given the huge resources implied and their questionable effectiveness (Driffield, forthcoming). Investment incentives have been discussed extensively and criticized generally as a crude, discriminatory and expensive tool for the attraction of inward FDI (Young, 2004, Vol I, chapters 13-17). Supporting these findings for the Belgian case, De Backer and Sleuwaegen consider that incentives risk being a waste of resources in the long run, and conclude that subsidies for FDI reinforce the competitive advantage of foreign-owned MNEs in a discriminatory way, enhancing crowding-out effects. Similarly De Propris et al., considering the case of FDI in local industrial systems (LISs), comment that subsidies to attract MNEs to such regions of agglomeration are unnecessary. They do, however, suggest that a range of inward investment incentives may still be required to attract FDI into lagging regions or those lacking specialized industrial areas. The provision of FDI subsidies per se is also questioned by Bellak, who argues that effective policy should respond to the mismatch between competitive and comparative advantage, rather than focusing only on the inward investors' side. In another paper, Bellak (2004) notes that the usually assumed performance gaps between foreign affiliates and domestic companies are not enough to justify discrimination against domestic producers.

The view of the present editors is that as long as investment incentives continue to be used (and there is little willingness for reform in developed countries), there should be a very transparent award and allocation system to ensure there is no discrimination in favour of foreign as opposed to indigenous enterprises. While discrimination is illegal under international and multilateral rules, indirect discrimination may occur through the terms under which incentives are allocated, and disguised incentives such as roads, free space in industrial parks, and favourable energy contracts commonly are used.

The existing weak multilateral system cannot prevent excessive competition or provide effective coordination (Young and Tavares, 2004). Even at sub-national 
level tough competition exists, producing a clear 'deadweight loss' (Tavares, 2001). In the EU context, there has been recently a great deal of controversy given the argument (and existing evidence) that intra-EU relocation is subsidized by EU funds (Ghauri and Oxelheim, 2003), and often the countries where divestments occur are net contributors to the EU Budget.

However, even if the effectiveness of incentives is highly questionable, as well as the relevance of incentives as FDI determinants (Root and Ahmed, 1979; Guisinguer et al., 1985), the fact is that offering them is hardly a choice-countries cannot escape opening their pockets, as all their competitors do, and that is definitely built into investors' expectations, who use the evidence to bargain with governments for the highest possible level of support (even when they would invest anyway due to other location factors). Clearly, incentive concession tends to create a prisoner's dilemma situation for the economies involved. Still, regarding FDI attraction, a pertinent question remains concerning the criteria used to allocate support. Prospective host countries tend to discriminate incentive concession according to, for instance, MNEs' chosen mode of establishment, usually supporting exclusively greenfield investments. Most of world FDI is, however, through acquisitions, but governments do not tend to support the purchase of domestic companies by foreign investors. This is justified by fears of loss of control and enhancing foreign firms' hegemony. Tackling this highly controversial area, Piscitello and Rabbiosi in this Special Issue disagree with this common policy approach, proposing promotion/attraction directed to the acquisition of local companies (LCs) by foreign-owned MNEs. In their opinion, this has the extra virtue of reducing the need for linkage policies since target local firms are embedded by definition. Moreover, it can be added, the foreign owner may bring, for instance, best managerial practices and stimulate a 'demonstration effect' to domestic firms that otherwise may not be exposed to such practices. Nevertheless, our intuition is that governments will be unlikely to support the acquisition of domestic companies in the near future.

The considerations made above point to the need to go beyond incentives of a traditional kind (financial and fiscal), as their effectiveness is doubtful. There are various other ways to increase the probability of FDI attraction. Basile (2004) notes the relevance of public research institutions and business services as attractors of MNEs' activities. Other authors writing in the present Issue (Bellak; Dimelis; Durán and Úbeda) emphasise the need to use short-term and long-term based measures, general and specific policies, including those strengthening economic fundamentals and the institutional system. That is indeed critical not only for attraction from a quantitative side, but also from a qualitative standpoint. That brings us to the next level, viz. the need to enhance the quality of MNEs' activities and therefore of their local impact.

\section{Maximizing Benefits to the Local Economy: Spillovers}

Attracting inward investment does not guarantee per se a positive effect on the host economy, or that the potential benefits can be maximised. There are important trade-offs, as the above review of the controversy surrounding incentive concession shows. The heart of the matter is that more and more policy-makers are trying to go beyond attraction and moving into the more ambitious terrain of promoting spillovers from MNEs' activities to domestic firms. There are several channels through which spillovers may occur, and spillovers can be of various 
kinds (technological, on productivity, wages, entrepreneurship, and so forth). Particular attention is dedicated in this Issue to effects on productivity.

The literature on spillovers is extensive (Caves, 1974; Globerman, 1975; Blomström and Persson, 1983; Blomström and Kokko, 1998; and the useful review in Görg and Greenaway, 2001) and highlights very mixed results and, therefore, varied effects of public policy directed to the enhancement of such spillovers.

Several studies found evidence of negative spillovers (Aitken and Harrison, 1999; Djankov and Hoekman, 2000; Kathuria, 2000; Castellani and Zanfei, 2003). Others found the opposite, i.e., positive spillover evidence (Hubert and Pain, 2001; Haskel et al., 2002; Keller and Yeaple, 2003). However, a considerable number of empirical studies provided inconclusive results or arrived at mixed evidence for different firms/countries (e.g. Haddad and Harrison, 1993; Girma et al., 2001; Konings, 2001; Damijan et al., 2003).

\subsection{Absorptive Capacity as a Prerequisite for Effective Linkages and Transfer of Firm-specific Advantages}

Even under the assumption that foreign investors have superior ownership advantages (Hymer, 1960/1976; Dunning, 1977), or firm-specific advantages (FSAs) ${ }^{1}$, their transfer to local firms is by no means automatic. One of the key aspects on which this transfer is contingent is absorptive capacity (Cohen and Levinthal, 1990). Absorptive capacity is one of the main themes discussed in the papers presented here (Barry et al.; De Backer and Sleuwaegen; Dimelis; Piscitello and Rabbiosi; Ruane and Uğur). The overall conclusion is that LCs that are MNEs (or at least that export, as Barry notes) have far greater absorptive capacity than their purely domestic counterparts (as they have a great deal of similarity, locallybased MNEs are easier conduits for spillovers).

Relevant determinants of absorptive capacity, and consequently, of the likelihood of spillovers, are: technological gap; cultural and psychic distance; inter-unit (receiver-sender) homophily (Gupta and Govindarajan, 2000); geographic proximity; idiosyncratic nature of industries and host countries; degree of foreign ownership; level of development of host economy; relative size of firms; degree of trade protection, and the institutional framework.

Regarding specifically the technological gap, the most accepted idea in the literature is that such a gap should not be too small (otherwise there is little room for improvement) or too wide (Wang and Blomström, 1992; Perez, 1997; Liu et al., 1999; Flores et al., 2000; Girma et al., 2001; Barrios and Strobl, 2002; Girma and Görg, 2002). Where the technological gap is too wide, policy cannot operate miracles, as "there are no spillovers if there is nothing to spill into" (Tavares, 2001). If this view is accepted, ${ }^{2}$ in order to promote spillovers, policies can aim at decreasing the technological (and institutional) gap. In this vein, Bellak and Durán and Úbeda stress the importance of investment in R\&D institutions, and in stimulating linkages between MNE subsidiaries and the domestic innovation system (in order to promote what De Backer and Sleuwaegen call 'active learning').

\subsection{Agglomeration, Clusters/Networks, Knowledge Sourcing and Embeddedness}

Another set of policies increasingly used are those aiming to promote agglomeration and cluster and network formation (Ruane and Ugurur). Geographic proximity (Jaffe et al., 1993) is expected to enhance the probability of positive spillovers. This 
has been translated into concrete policy measures in various countries. In this Issue, authors like Bellak, Durán and Úbeda, Ruane and Uğur mention such initiatives. De Propris et al. refer to an 'amplifying effect' of clusters on spillovers. They argue that Local Industrial Systems (LISs) are related positively to MNEs' location choice, and provide a genuine source of competitive advantage, given the uniqueness of specialisation, tacitness of knowledge, localised (collective) learning and particular governance structures (each configurating a 'nexus of untraded interdependencies', Storper, 1997) that are sought specifically by certain inward investors. ${ }^{3}$ This is particularly relevant for investors that have a knowledge-sourcing motivation (Kogut and Chang, 1991; Cantwell, 1995; Neven and Siotis, 1996; Pearce, 1999). ${ }^{4}$

Nonetheless, embeddedness is no easy task. De Propris et al. note the difficulty for large firms when trying to embed in LISs, as there are barriers to enter into existing networks (Bellandi, 2001), such as collective learning processes that need considerable time to develop, and that have idiosyncratic coordination and governance mechanisms that are not easy to grasp.

Despite this difficulty, stimulating embeddedness/linkages is considered desirable. Linkages imply that MNEs have incurred sunk costs and thus are less likely to abandon the host economy in the short term (Driffield and Mohd Noor, 2000). Papers in this Issue endorse this idea (Bellak; De Propris et al.; Ruane and Ugur). Piscitello and Rabbiosi provide a practical, yet controversial, suggestion to enhance embeddedness: to promote acquisitions of domestic firms, as these are embedded 'more or less by definition'.

All articles published here deal in one way or another with impact issues. The most addressed topic refers to productivity spillovers, studied thoroughly in five of the papers (Barry et al.; Dimelis; De Backer and Sleuwaegen; Piscitello and Rabbiosi; Ruane and Uğur). Most of these articles acknowledge the stylised fact that productivity tends to be greater in foreign subsidiaries than in domestic firms, although a positive impact on the productivity of LCs was not found in most cases. A relevant issue discussed in some of the papers (Dimelis; Ruane and Uğur), that may offer a key to understanding the variability in results, relates to the methodological approach used, namely whether panel data or cross-section analyses were undertaken. All papers included here are based on recent comprehensive firmlevel datasets and panel data approaches, hence providing a more solid guarantee of robustness, and greater reliability than cross-section studies (Kugler, 2000; Görg and Greenaway, 2001). The panel data approach is better as it can account for dynamic and unobservable firm-specific effects, whereas cross-section analyses may lead to biased and inconsistent estimates (Dimelis). Ruane and Uğur took the issue further and tested distinct levels of aggregation and alternative measures of MNE presence, finding that results were contingent on such different levels and measures. Overall, the analyses reported in this Special Issue provide support for the results of previous firm-level panel data studies, ${ }^{6}$ viz., no evidence of spillovers, or negative results. Hence, conclusions are cautious and not always in agreement.

De Backer and Sleuwaegen support the development of a techno-economic infrastructure aimed at clustering foreign and domestic investments, allied to policies designed to stimulate technological development and international exploitation of technological advantages. These are considered as the best options for the successful development of a sustainable industrial base. While such measures increase the likelihood of spillovers, the authors indicate that there is no guarantee that they will happen automatically. In addition, they stress the 
importance of supportive investments in absorptive capacity. In a similar vein, De Propris et al's. work suggests that local industrial systems have attracted MNEs that wish to become embedded locally, a result that applied to both high and low technology manufacturing. However, their follow-up proposal - that FDI policy needs to be selective and strategic to ensure that MNEs commit to a location and take a long-term perspective on their investment-may not be practical and certainly would be difficult to implement.

Ireland represents a classic case of a country pursuing an economic development strategy based upon the attraction of greenfield manufacturing FDI. However, employment creation was the main objective of the strategy for many years. As Ruane and Uğur show, based on a comprehensive plant-level dataset, it was only in the mid-1990s that there was a policy shift to promote the indirect impacts of FDI, through building linkages between the domestic and foreign sectors and supporting manufacturing agglomerations. The work of Ruane and Ugur indicates limited productivity spillovers, which they explain by the somewhat contradictory nature of Irish policy. ${ }^{7}$ Thus a key plank of policy has continued to be the promotion of Ireland as an export platform that encourages the sourcing of inputs abroad. In a similar way, the large productivity gap between the two sectors may reduce absorptive capacity.

New policies have thus been introduced to enhance the productivity of domestic enterprises through further emphasis on clusters and networks to assist knowledge transfers; and building up supply chains ${ }^{8}$ (both intra- and intersectoral) between MNEs and LCs (especially targeting electronics and healthcare products). But Ruane and Uğur remain cautious, commenting that: 'It remains to be seen whether these new policies will succeed, where earlier policies have not, in generating productivity in Irish manufacturing'. Interestingly, by comparison, Barry et al. are much more sanguine about impacts in Ireland, and comment that their findings 'should not give rise to undue policy concerns'. This may be a somewhat surprising conclusion in the light of their findings. Thus, the Barry et al study indicates that domestic non-exporters in Ireland do not benefit from productivity spillovers; while domestic non-exporters are adversely affected by labour market crowding-out by foreign-owned firms. As absorptive capacity is low, productivity spillovers are dominated by crowding-out, and the two effects cannot be disentangled empirically (Barry et al.). Their optimistic perspective derives from other positive evidence on the impact of MNEs on spillovers in Ireland (Görg and Strobl, 2002, 2003), and, they believe, from the nature of their sample that excludes very small Irish firms, where they consider spillovers are likely from their role as sub-suppliers. However, this suggestion perhaps runs counter to the absorptive capacity hypothesis (e.g., supported by Dimelis in this Issue). Looking at the body of evidence on spillovers from countries other than Ireland, there are again very mixed messages from the plethora of policy initiatives at the firm- and industry-levels. The results in this Issue strongly support the need to raise the absorptive capacity of domestic enterprises, and several authors suggest ways of doing this. Growing locally-owned MNEs is an important one of these. That leads us to discuss policies designed to stimulate outward FDI.

\section{Outward FDI and Public Policy}

From the previous section, there was a difference in respect of whether LCs were or not MNEs themselves. This has a bearing on the inward-outward link, and on 
the dynamic interaction between FSAs and location advantages (LAs). In this Issue, it is claimed (Bellak; De Backer and Sleuwaegen; Durán and Úbeda) that the development of FSAs constitutes a prerequisite to compete successfully abroad. As Caves (1996) stated, firms do not become multinationals unless they are good at doing something.

Here, Durán and Úbeda provide a theoretical reformulation of the fourth stage of the investment development path (IDP) model (developed initially by Dunning in 1981). Developed nations in Stage 4 (which include a number of the countries analyzed in the articles in this Issue, namely, Austria, Ireland and Italy) show a technological and institutional 'gap' compared with those in Stage 5. This is revealed in their lower capacity to generate outward FDI, whereas there are no significant differences between the two groups in their ability to attract inward FDI. The authors conclude that governments need to increase their countries' endowment of knowledge-intensive assets through an institutional environment that enhances absorptive capacity. In the short-run, governments should aim to reduce the transaction costs of $R \& D$ and innovation systems, meaning tax incentives to facilitate inter-firm technological alliances among and between firms and the scientific community, and support for innovation. From a longer-term perspective, there is a requirement for higher investment in health, education and infrastructure. In sum, Durán and Úbeda envisage an important role for public policy in stimulating the inward-outward investment dynamic, and that Government action should occur at various levels (short-term, long-term, general and specific, promoting LAs but also the development of FSAs in companies based in their jurisdiction).

Bellak's paper addresses related issues, commenting that his paper may be regarded as 'an analysis of the underlying forces of the investment development path'. His work highlights the different adjustment strategies of domestic and foreign-owned firms to changing national competitiveness, as applied to the case of Austria. The distinction between the sources of competitiveness - comparative and competitive advantage-is very useful from a policy perspective, since it distinguishes between measures directed to improving locational advantages and firm-specific advantages (FSAs). The former essentially concern investment in public goods, infrastructure, regulation, while policies to improve FSAs range from industry-related subcontracting initiatives to financing and guarantee schemes, to R\&D collaboration, technological policies, and direct support for outward internationalisation (Bellak). Domestic firms may be able to take advantage of favourable location factors to a greater extent than foreign firms, and thus compensate for their lack of firm-specific advantages. But this only applies to their domestic operations. In order to develop outward FDI, firm-specific advantages (particularly technological capabilities) are essential (a conclusion reinforced by De Backer and Sleuwaegen); and policy-makers still need to understand that the encouragement of multinational operations is a prerequisite for long-term success in global markets. Bellak defends policies to improve the match between FSAs and LAs. Like Durán and Úbeda, policy intervention of various kinds and at diverse levels is preferred. Different levels of intensity and content, as appropriate, are recommended to improve the match between comparative and competitive advantage.

The article by De Backer and Sleuwaegen analyzes the productivity advantages of foreign-owned MNEs in Belgium and concludes that these relate to both scale and efficiency effects. However, the advantages are most evident in 
comparison with Belgian domestic firms. Belgian MNEs, by contrast, resemble foreign-based MNEs. These results apply even after controlling for industry differences. The authors argue that through international growth, Belgian MNEs can match the productive efficiency of foreign firms and hence reduce 'crowding-out' effects. This conclusion is supported indirectly by Dimelis' study on spillovers from inward FDI in Greece. The work shows that spillovers to domestic firms are greater in the middle and upper quartiles of the growth distribution (supporting the absorptive capacity hypothesis), where there is greater technological complementarity with foreign affiliates. Although the research did not distinguish Greek-owned MNEs, such firms are likely to be present in the higher end of the growth distribution.

According to De Backer and Sleuwaegen, in Belgium the productivity advantage of foreign affiliates is clearly linked to their technological capabilities. However, productivity is influenced by many factors beyond technological advantages, among which are whether companies belong to a multinational network. To these authors, multinationality matters more than foreignness in explaining productivity, an opinion corroborated by Piscitello and Rabbiosi. These results are in line with Pfaffermayr and Bellak (2000), who found that the productivity and profitability gap could not be explained by foreign ownership per se, but by belonging to a multinational network permitting effective exploitation of FSAs.

The articles in this Issue thus add significantly to existing thinking in respect of outward FDI, revealing the relevance of locally-based MNEs for the domestic economy. Aside from being a necessary constituent of the globalisation process for domestic firms, locally-based MNEs may generate productivity gains for the local economy and also promote spillovers from inward FDI because of their higher absorptive capacity.

Despite such benefits, policy debate concerning outward FDI and domestic MNEs has been quite limited. Taking a historical perspective, subsequent to the liberalisation of capital controls at the macro-level (still a relatively recent event in some developed countries), public policies were designed to assist outward FDI through information and technical assistance; direct financial support, technical assistance and fiscal incentives; and investment insurance (UNCTAD, 1995). The articles in this Issue, by comparison, mainly emphasise generic or industry-level policies designed to improve firm-specific advantages either directly (e.g., technological alliances, as Durán and Úbeda suggest) or indirectly through investment in public goods (Bellak). The requirement for developing technological capabilities/advantages in order to compete abroad is generally accepted; although, as discussed below, outward FDI is not simply about the exploitation of FSAs, as in market-seeking or efficiency-seeking FDI, but may also take the form of assetaugmenting (Pearce, 1989; Kuemmerle, 1999) or strategic-asset seeking (Dunning, 1993) investment.

Evidence of this 'exploration' attitude is highlighted by other research in the international business field that has begun to explore the contribution of foreign subsidiaries to the parent MNE's resources and capabilities (White and Poynter, 1984; Pearce, 1989; Birkinshaw, 1996; Alorbi, 2003). Yamin (1999) and Håkanson and Nobel (2000) found evidence of reverse technology transfer from the subsidiary to the parent. Similarly Forsgren, Pedersen and Foss (1999) concluded that the internal factors (capabilities) of a subsidiary directly impact on the organisational strength of the subsidiary and the MNE as a whole. 
In considering policy issues associated with promoting and generating outward FDI, it is useful to analyze the nature of outward investors and their entry and development strategies. Local firms seeking to become MNEs may be very heterogeneous, from large companies (often embarking on acquisitions) to SMEs.

Two issues are considered here, first, the role of cross-border mergers and acquisitions (M\&As); and, second, the generation of small firm MNEs.

\subsection{Acquisition-based Outward FDI}

Evidence from UNCTAD (2000) has highlighted the importance of M\&As in global investment flows (recognising the role of acquisitions in privatization processes). Although there is limited evidence, a hypothesis might be that for many larger domestic firms, the route to multinationality is through acquisitions, for the well-known reasons of speed, increased size, the search for new markets and market power, efficiency gains and diversification, as well as personal and financial motives (UNCTAD, 2000). However, an additional motivation concerns investment overseas to access strategic assets to augment existing firm-specific advantages. Kuemmerle (1999) distinguished between firms which are homebase-exploiting MNEs and those which are home-base-augmenting MNEs. British FDI in the US is a classic case of asset-augmenting FDI, pointed out in the early work of Reddaway et al. (1968) and Houston and Dunning (1976), and still is the case currently (Alorbi, 2003). Given that British firms are not generally dominant in advanced technology, their main FSAs may lie in production management and organizational capabilities (Howenstine and Shannon, 1996).

The basic question from a public policy perspective is whether acquisition is an area where governments can or should intervene (see Piscitello and Rabbiosi in this Issue). In terms of identifying and implementing M\&As, there is no clear evidence of market failure. Management consulting firms are very active in the provision of advisory services to potential acquirers in all areas of M\&A management.

It might be argued that government could have a role in assisting firms with locational targeting, especially in regard to entry into new and emerging markets (to assist both acquisition and greenfield ventures). Research (e.g., Shaver and Flyer, 2000) has shown that low-technology firms that locate in proximity to knowledge clusters can benefit from that association in respect of employee recruitment, supplier and distributor access and knowledge spillovers. In addition, there may be requirements for support to companies in the post-acquisition period, concerning, for example, identifying and facilitating knowledge transfers. But, in reality, much more evidence is required before specific policy proposals could be developed. This is a highly controversial area, as in terms of public opinion a lot has to be proven before policy-makers would embark on such initiatives.

\subsection{Internationalization of SMEs and Promoting Micromultinationals (mMNEs)}

While larger firms may possess the resources to employ M\&As as an international entry and expansion strategy, SMEs need to exploit their flexibility to succeed internationally. It is still the case that many will develop from exporting into more committed modes including multinationality. Dimitratos et al. (2003) use the term micromultinationals to refer to a newer and growing breed of SMEs that control 
and manage value-added activities through constellation and investment (rather than exporting) modes in more than one country. Such mMNEs include the socalled 'international new ventures' that have been studied by researchers since the 1990s (e.g., McDougall et al., 1994; Knight et al., 2000) and operate in foreign markets through interorganizational networks, alliances and subsidiaries.

There is a wide range of government support measures for exporters, reflecting the easily identifiable benefits from increased overseas trade. However, in the light of the internal and external economic benefits accruing to the home economy from multinationality, there is also a case for supporting mMNEs more specifically. Although research on mMNEs has been limited, initial findings suggest that success factors (firm-specific advantages) for mMNEs comprise (a) founder and top management global vision and experience; (b) knowledgeable human capital and financial resources; (c) networking capabilities; and (d) adaptation strategies to meet the demands of foreign customers (Dimitratos et al., 2003; Johnson, 2001).

The nature of such FSAs suggests that micro-level public policy support is required alongside any generic policies as discussed above; and there are beginning to be some interesting initiatives directed to addressing market failures and enhancing FSAs at the firm level. One example is that of the Global Companies Development Programme (GCDP) which is designed to assist the international/ global expansion of Scottish SMEs (many of which are or will become mMNEs) (Young, 2003). This is an individually tailored support programme that emphasizes strategic review and implementation, with access to generic government support programmes as appropriate. Early evaluation results of the programme have revealed very positive results in terms of international development, including, for example, the replacement of opportunistic internationalization by a more strategic approach; the creation of new business models to pursue international expansion; and improvements in management and organization structures through internal management development or external recruitment.

Evidence from other such policy programmes directed to outward investment and associated forms of activity clearly is required. Similarly the economic interactions of outward and inward FDI that have emerged strongly in the papers in this Special Issue require fuller investigation. The articles in this Issue emphasize the need for more (and rigorous) empirical work, particularly to disentangle types of impact, clarify relationships, and capture long-term effects.

\section{Final Remarks}

The articles in this Special Issue recognize a role for policy vis-à-vis FDI, with distinct levels of proactivity advocated, as well as various complementary policy approaches (macro-, meso-, or micro-focused). The most appropriate policy choices do not have to be FDI-focused, or FDI-specific, and often general policies addressing economic fundamentals and broader issues are deemed more desirable.

It is claimed that attraction (quantity) tout court does not suffice, and that promoting embeddedness (quality) is a worthwhile pursuit, though hard to implement. Several authors note in this Issue that there was, in many countries, a change of focus from FDI attraction per se to promoting clusters of domestic firms and linkages between and among domestic companies and foreign affiliates. Specific measures directed at indigenous firms, in order to enhance the absorptive capacity of the local economy, are repeatedly recommended. 
Another strong idea is that FDI benefits cannot be taken for granted, ${ }^{9}$ hence there must be caution in the award of FDI incentives, and discrimination against domestic companies should not occur. The articles here also point to the need to conceptualize and study further the inward-outward FDI dynamic, as understanding this relationship may have considerable competitiveness and development implications. In the same line of reasoning, this implies understanding better the interaction between FSAs and LAs, trying to promote synergies and a better match between comparative and competitive advantage.

In this Issue, several FDI impact areas are evaluated, leading to a variety of results and corresponding policy prescriptions. As results on impact differ according to the reality under analysis, each policy recommendation should be contextualised and not presumed to represent a general panacea. There are always trade-offs and certainly no free lunches. For each situation, policy-makers should be able to assess alternative paths on policy content and implementation, hopefully bearing in mind the importance of consistency and not losing sight of the long-run effects.

\section{Notes}

1. Both expressions-firm-specific advantages (FSAs) and ownership advantages will be used interchangeably.

2. However, Castellani and Zanfei (2003), cited by Dimelis questioned the tendency in the literature to associate high (low) technological gaps with low (high) absorptive capacity. They argued that, due to heterogeneity between firms and sectors, high (low) gaps can be associated with both high and low absorptive capacity.

3. Camagni (2002) differentiates LISs from agglomeration economies: whereas the first generate competitive advantages at firm level, the second merely provide a source of comparative advantage (for more remarks on the distinction between comparative and competitive advantage see Bellak in this Issue).

4. The importance of intangible (strategic) assets as a motivation for FDI in developed economies (Dunning, 1993) is now fully recognized. The papers in this Special Issue focus on developed economies, characterized by high labour (and other) costs vis-à-vis some developing/emergent locational competitors, so most likely an important part of new investment projects will contain a knowledge-intensive component.

5. Barry et al. claim that even the replacement of indigenous by foreign firms is unlikely to have adverse linkage effects, given that: $\mathrm{R} \& \mathrm{D}$ expenditure per employee is far greater in foreign industry and in FDI-intensive sectors; and that does not worsen employment stability. Thus, Barry et al. do not consider there should be big policy concerns re FDI impact on these variables.

6. Exceptions to this generalization are recent papers based on panel data by Haskel et al. (2002) and Keller and Yeaple (2003) that found evidence of positive spillovers.

7. Ruane and Uğur argue that there were a priori several reasons why positive spillovers should be expected in Ireland: consistent FDI promotion and encouragement to link MNEs-LCs; export orientation: MNEs don't compete with LCs, decreasing thus the likelihood of negative spillovers; high unemployment in Ireland until recently, making crowding-out less likely; common language and shared culture with the largest inward investor (the US); easy mobility of labour between MNEs and LCs; fewer impediments to imitation. In any case, even if these 'spillover channels' were in place, their findings contradict this expectation.

8. A growing number of countries are implementing supplier development programmes, such as Ireland (National Linkage Programme, mid-1980s), the Czech Republic (National Supplier Development Programme, 1999), and Hungary (Integrators' Subcontracting Programme, 1998). The results of such programmes have been thought as positive.

9. Lovering's (2003) opinion is that "at the practical level (...) the policy biases in favor of FDI are very rarely based on anything even remotely approaching a thorough and objective empirical examination of its past contribution and future potential impact on the economy as a whole (...). Where such examination has been attempted it has sometimes been rudimentary or flawed". 


\section{References}

Aitken, B.J. and Harrison, A. (1999) Do domestic firms benefit from direct foreign investment? Evidence from Venezuela, American Economic Review, 89(3), pp. 605-18.

Alorbi, K.C. (2003) The activities of UK Multinationals in the US: A study of strategy and structure evolution, unpublished PhD thesis, Glasgow, UK: University of Strathclyde, October.

Barrios, S. and Strobl E. (2002) Foreign direct investment and productivity spillovers: Evidence from the Spanish experience, Weltwirtschaftliches Archiv, 138, pp. 459-81.

Basile, R. (2004) Acquisition versus greenfield investment: The location of foreign manufacturers in Italy, Regional Science and Urban Economics, 34(1) pp. 3-25.

Bellak, C. (2004) How performance gaps between domestic and foreign firms matter for economic policy, Transnational Corporations, 13(2), pp. 29-55.

Bellandi, M. (2001) Local development and embedded large firms, Entrepreneurship E Regional Development, 13(3), pp. 189-210.

Birkinshaw, J. (1996) How multinational subsidiary mandates are gained and lost, Journal of International Business Studies, 27(3), pp. 467-95.

Blomström, M. and Kokko, A. (1998) Multinational corporations and spillovers, Journal of Economic Surveys, 12(3), pp. 247-77.

Blomström, M. and Persson, H. (1983) Foreign investment and spillover efficiency in an underdeveloped economy: Evidence from the Mexican manufacturing industry, World Development, 11, pp. 493-501

Camagni, R. (2002) On the Concept of territorial competitiveness: Sound or misleading? Urban Studies, 39(13) pp. 2395-2411.

Cantwell, J.A. (1995) The globalisation of technology: what remains of the product cycle model? Cambridge Journal of Economics, 19(1), pp. 155-74.

Castellani, D. and Zanfei, A. (2003) Technology gaps, inward investments and productivity of European firms, Economics of Innovation and New Technology, 12(6), pp. 555-76.

Caves, R. (1974) Multinational firms, competition and productivity in host-country markets, Economica, 41, pp. 176-93.

Cohen, W.M. and Levinthal, D.A. (1990) Absorptive capacity: a new perspective on learning and innovation, Administrative Science Quarterly, 35, pp.128-52.

Damijan, J.P., Knell, M., Majcen, B. and Rojec, M. (2003) Technology transfer through FDI in top-10 transition countries: How important are direct effects, horizontal and vertical spillovers? William Davidson Working Paper Number 549.

Dimitratos, P., Johnson, J.E., Slow, J. and Young, S. (2003) Micromultinationals: New types of firms for the global competitive landscape, European Management Journal, 21(2), pp.164-74.

Djankov S. and Hoekman B. (2000) Foreign investment and productivity growth in Czech enterprises, World Bank Economic Review, 14(1), pp. 49-64.

Driffield, N.L. (forthcoming) Regional policy and spillovers from FDI in the UK, Annals of Regional Science.

Dunning, J.H. (1977) Trade, location of economic activity and the MNE: a search for an eclectic approach, in: B. Ohlin, P.O. Hesselborn and P.M. Wijkman (Eds), The International Allocation of Economic Activity, pp. 395-418 (London: Macmillan).

Dunning, J.H. (1981) Explaining the international direct investment position of countries: towards a dynamic or developmental approach, Weltwirtshaftlichers Archive, 119, pp. 30-64.

Dunning, J.H. (1993) Multinational Enterprises and the Global Economy (Wokingham, UK: Addison Wesley).

Flores, G., Renato, J.R., Fontura, M.P. and Santos, R.G. (2000) Foreign direct investment spillovers: What can we learn from Portuguese data?" Mimeo, ISEG, Technical University of Lisbon.

Forsgren, M., Pedersen, T. and Foss, N.J. (1999) Accounting for the strengths of MNC subsidiaries: The case of foreign-owned firms in Denmark, International Business Review, 8(2), pp. 181-96.

Ghauri, P. and Oxelheim, L. (Eds) (2003) European Union and the Race for Foreign Direct Investment in Europe (Oxford: Elsevier).

Girma, S., Greenaway, D. and Wakelin, K. (2001) Who benefits from foreign direct investment in the UK? Scottish Journal of Political Economy, 48(2), pp. 119-33.

Girma, S. and Görg, H. (2002) Foreign ownership, returns to scale and productivity: Evidence from UK manufacturing establishments, CEPR Discussion Papers, no. 3503, London: CEPR.

Globerman, S. (1975) Technological diffusion in the Canadian tool and dye industry, The Review of Economics and Statistics, 57(4), pp. 428-34.

Görg, H. and Greenaway, D. (2001) Foreign direct investment and intra-industry spillovers, http:// www.unece.org/ead/misc/ffd2001/greenaway.pdf 
Görg, H. and Strobl, E. (2002) Multinational companies and indigenous development: An empirical analysis, European Economic Review, 46, pp. 1305-22.

Görg, H. and Strobl, E. (2003) Multinational companies, technology spillovers and plant survival, Scandinavian Journal of Economics, 105, pp. 581-95.

Guisinguer, S. et al. (1985) Investment Incentives and Performance Requirements (New York: Praeger).

Gupta, A.K. and Govindarajan, V. (2000) Knowledge flows within multinational corporations. Strategic Management Journal, 21, pp. 473-96.

Haddad, M. and Harrison, A. (1993) Are there positive spillovers from direct foreign investment? Evidence from panel data for Morocco. Journal of Economic Development, 42, pp. 51-74.

Håkanson, L. and Nobel, R. (2000) Technology characteristics and reverse technology transfer, Management International Review, 40(1), pp. 29-48.

Haskel, J. E., Pereira, S. C. and Slaughter, M. J. (2002) Does inward foreign direct investment boost the productivity of domestic firms? NBER Working Paper No: 8724.

Howenstine, N.G. and Shannon, D.P. (1996) Differences in foreign-owned US establishments by country of owner, Survey of Current Business, March, pp. 43-60.

Houston, T. and Dunning, J.H. (1976) UK Industry Abroad (London: Financial Times Publications).

Hubert, F. and Pain, N. (2001) Inward investment and technical progress in the United Kingdom manufacturing sector, Scottish Journal of Political Economy, 48(2), pp. 134-47.

Hymer, S. (1960/1976) The International Operations of National Firms: A Study of Direct Foreign Investment (Cambridge, MA: MIT Press).

Jaffe, A.B., Trajtenberg, M. and Henderson, R. (1993) Geographical localization of knowledge spillovers as evidenced by patent citations, Quarterly Journal of Economics, 63(3): pp. 577-98.

Johnson, J.E. (2001) Firm-specific Determinants of Success for Small High-Technology International Start-Ups: A performance study of UK and US firms, unpublished PhD thesis, Glasgow, UK: University of Strathclyde.

Kathuria, V. (2000) Productivity spillovers from technology transfer to Indian manufacturing firms, Journal of International Development, 12, pp. 343-69.

Keller, W. and Yeaple, S.R. (2003) Multinational Enterprises, International Trade, and Productivity Growth: Firm Level Evidence from the United States, NBER Working Paper 9504.

Kogut, B. and Chang, S.J. (1991) Technological capabilities and Japanese foreign direct investment in the United States, Review of Economics and Statistics, 73, pp. 401-13.

Konings, J. (2001) The effects of foreign direct investment on domestic firms, Economics of Transition, 9(3), pp. 619-33.

Knight, G., Madsen, T.K., Servais, P. and Rasmussen, E. (2000) The born global firm: Description and empirical investigation in Europe and the United States, American Marketing Association Conference, Winter.

Kuemmerle, W. (1999) The drivers of foreign direct investment into research and development: An empirical investigation, Journal of International Business Studies, 30(1), pp. 1-24.

Kugler, M. (2000) Externalities from Foreign Direct Investment: The Sectoral Pattern of Spillovers and Linkages, http://elsa.berkeley.edu/users/bardhan/e271_f01/nov5.pdf

Liu, X., Siler, P., Wang, C. and Wei, Y. (2000) Productivity spillovers from foreign direct investment: evidence from UK industry level panel data, Journal of International Business Studies, 31(3), pp. 407-25.

Lovering, J. (2003) MNCs and wannabes-inward investment, discourses of regional development, and the regional service class, in: N. Phelps and P. Raines (Eds), The New Competition for Inward Investment Companies, Institutions and Territorial Development (Cheltenham, UK: Edward Elgar).

McDougall, P.P., Covin, J.G., Robinson, J.J. and Herson, L. (1994) The effects of industry growth and strategic breadth on new venture performance and strategy content, Strategic Management Journal, 15, pp. 537-54.

Mytelka, L.K. (2000) Locational tournaments for FDI: inward investment into Europe in a global world, in: N. Hood and Young, S. (Eds), The Globalization of Multinational Enterprise Activity and Economic Development, pp. 278-302 (London: Macmillan).

Neven, D. and Siotis, G. (1996) Technology sourcing and FDI in the EC: an empirical evaluation, International Journal of Industrial Organisation, 14, pp. 543-60.

O'Donnellan, N. (1994) The presence of Porter's clustering in Irish manufacturing, Economic and Social Review, 25(3), pp. 221-32.

Pearce, R.D. (1989) The Internationalisation of Research and Development by Multinational Enterprises (New York: St. Martin's Press).

Pearce, R.D. (1999) Decentralised R \& D and strategic competitiveness: globalised approaches to generation and use of technology in multinational enterprises (MNEs), Research Policy, 28, pp. 157-78. 
Perez, T. (1997) Multinational enterprises and technological spillovers: an evolutionary model, Journal of Evolutionary Economics, 7(2), pp. 169-92.

Pfaffermayr, M. and Bellak, C. (2000) Why foreign-owned firms are different: a conceptual framework and empirical evidence from Austria, HWWA Discussion Paper 115.

Reddaway, W.P., Potter, S.J. and Taylor, C.T. (1968) Effects Of UK Direct Investment Overseas: Final Report (Cambridge: Cambridge University Press).

Rodríguez-Clare, A. (1996) Multinationals, linkages and economic development, American Economic Review, 86(4), pp. 852-73.

Root, F.R. and Ahmed, A.A. (1979) Empirical determinants of manufacturing direct foreign investment in developing countries, Economic Development and Cultural Change, 27(4), pp. 751-67.

Shaver, J.M. and Flyer, F. (2000) Agglomeration economies, firm heterogeneity and foreign direct investment in the United States, Strategic Management Journal, 21, pp. 1175-93.

Storper, M. (1997) The Regional World: Territorial Development in a Global Economy (London: Guildford Press).

Tavares, A.-T. (2001) Systems, Evolution and Integration: Modelling the Impact of Economic Integration on Multinationals' Strategies,' Unpublished Ph.D. Thesis, University of Reading, UK.

Tavares, A.-T. and Young, S. (2003) EU periphery and the quality of manufacturing FDI, in: P. Ghauri and L. Oxelheim (Eds) European Union and the Race for Foreign Direct Investment in Europe, pp. 257-87 (Oxford: Elsevier).

Van Egeraat, C. and O'Malley, E. (1999) Porter's industry clusters in Irish indigenous industry, Working Paper No. 119. Dublin: The Economic and Social Research Institute.

UNCTAD (1995) World Investment Report 1995. Transnational Corporations and Competitiveness (New York and Geneva: UN).

UNCTAD (2000) World Investment Report 2000. Cross-border Mergers and Acquisitions and Development (New York and Geneva: UN).

UNCTAD (2003) World Investment Report 2003: FDI Policies for Development: National and International Perspectives (New York and Geneva: UN).

Wang, J.-Y. and Blomström, M. (1992) Foreign investment and technology transfer: a simple model, European Economic Review, 36, pp. 137-55.

Yamin, M. (1999) An evolutionary analysis of subsidiary innovation and 'reverse' transfer in multinational companies, in: F. Burton, M. Chapman and A. Cross (Eds) International Business Organization, Subsidiary Management, Entry Strategies and Emerging Markets (Basingstoke, UK: Macmillan).

Young, S. (2003) The Global Companies Development Programme and Micromultinationals, Presentation at the EUNIP Annual Conference, University of Porto, September.

Young, S. (Ed) (2004) Multinationals and Public Policy (Cheltenham, UK: Edward Elgar).

Young, S. and Tavares, A.-T. (2004) Multilateral rules on FDI: do we need them? Will we get them? A developing country perspective, Transnational Corporations, 13(1), pp. 1-30. 